\title{
THE INFLUENCE OF POLITICAL REGIMES \\ ON ROMANIAN PSALTIC MUSIC \\ IN THE SECOND HALF OF THE $20^{\mathrm{TH}}$ CENTURY
}

\author{
Professor Ph.D., habil, ELENA CHIRCEV \\ National Academy of Music “Gheorghe Dima” of Cluj-Napoca
}

Elena CHIRCEV, musicologist-byzantinologist, publicist, habilitated professor at the Theoretical Faculty of the "Gheorghe Dima" Academy of Music of Cluj-Napoca, Department of Musicology. Ph.D. in Musicology since 1998, with a thesis in the field of Byzantine music. Participation in national and international symposiums. Numerous studies and articles published in professional journals. Published books: Muzica românească de tradiție bizantină între neume și portativ [Romanian Music of Byzantine Tradition Between Neumes and Staves], 1st and 2nd vol. (2002, 2nd edition 2013), Amprente românești în muzica bizantină [Romanian Imprints in Byzantine Music] (2013), Mărturii și dialoguri

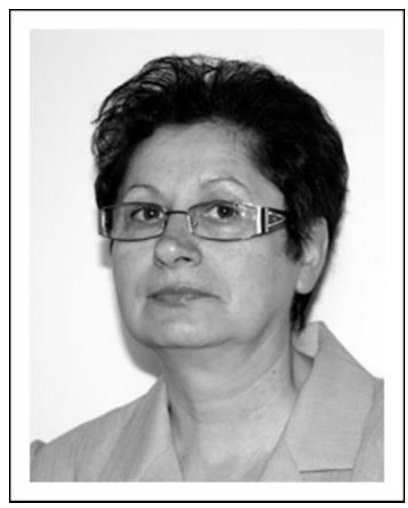
despre muzica bizantină [Testimonies and Dialogues about Byzantine Music] (2013). Editor at Radio "Renașterea" (1999-2013), regular contributor to the "Renașterea" magazine (since 2004), editor-in-chief of the "Intermezzo" journal (2008-2009) and of the bilingual journal "Lucrări de Muzicologie" / "Musicology Papers" (since 2009).

\section{ABSTRACT}

During the second half of the $20^{\text {th }}$ century, the Romanian society was marked by two events that had a profound impact on its destiny: the establishment of the communist regime after the abdication of King Michael I in 1948, and the Romanian Revolution of 1989, which marked the end of this regime. The Byzantine monody has had a millenary tradition in this part of Europe, and the contribution of the local chanters to the perpetuation of Orthodox church music - also through their own compositions - is evidenced by the numerous manuscripts written by Romanian authors and by the works printed in the last two centuries. In $20^{\text {th }}$-century Romania, the music written in neumatic notation specific to the Orthodox Church manifested itself discontinuously due to the historical events mentioned above. The church chant in the traditional psaltic style managed to survive, despite being affected by the Communist Party's decisions regarding the Church, namely the attempt to standardize the church chant. This paper captures the way in which the preservation of tradition and the perpetuation of church music succeeded through the difficult times of the communist period, with special emphasis on the religious music written in neumatic notation and on certain peculiarities of the period, due to the political regime. The musicians trained before the establishment of Communism - by teachers concerned with the preservation of the good tradition of church chanting, in monastic schools and prestigious 
theological seminaries of the interwar period - were the binding forces who ensured the rapid revival of the music of Byzantine tradition in the last decade of the $20^{\text {th }}$ century and who enriched the repertoire of the Romanian churches with valuable original works.

Keywords: Byzantine monody, communist period, neumatic notation, Romanian Revolution of 1989, tradition

\section{Introduction}

For the Romanian society, the daily, social-political and economic life, as well as the artistic and spiritual manifestations of the second half of the $20^{\text {th }}$ century have always been considered in relation to two temporal landmarks, two crucial moments in the recent Romanian history: the years 1947 and 1989, in which the political regime shifted from royalty to communism, and then from the totalitarian regime to democracy.

The words "before" and "after" are often used to evoke those dramatic events in Romania's history, which also influenced the Orthodox church music. "Before" the forced abdication of His Majesty King Michael I of Romania, on December 30, 1947, church music had followed its natural course of its millenary evolution, in line with the Byzantine tradition rigorously followed over the centuries and had arrived, through the contribution of the successive generations of local chanters, at the completion of the so-called process of "Romanianization". "Before" the Revolution of December 1989, there had been decades of persecution and stagnation, of resignation and struggle for survival of the Church in the harsh conditions imposed by the communist leadership, because "after" 1947 there began the persecution and reprisals by the atheist state. However, "after" 1989, the resistance of the persecuted, along with the decisions and efforts of the church leaders, made it possible for church music to regain its natural course and to undergo a considerable development, as also reflected in church music composition. Despite being affected by the decisions of the Communist Party regarding the Church, the church chant in traditional psaltic style has survived, because the musicians trained before the establishment of Communism - by teachers concerned with the preservation of the good tradition of the church chant in monastic schools and prestigious theological seminaries of the inter war period - were the binding forces who ensured the rapid revival of the music of Byzantine tradition in the last decade of the $20^{\text {th }}$ century and who enriched the repertoire of the Romanian churches with valuable original works. 
As we could see in a previous study - occasioned by the $100^{\text {th }}$ anniversary of the Great Union of $1918^{1}$-, church chant composition was, over the centuries, a constant preoccupation of the Romanian chanters. However, when studying the Byzantine musical manuscripts belonging to our national heritage, musicologists focused their attention mainly on the composers of the medieval period. While the field of Byzantine music research in the communist period was remarkably analysed by musicologist Nicolae Gheorghiță in a study conducted in recent years², psaltic music composition still remains a field in need of further exploration ${ }^{3}$. Therefore, we will try to show the way in which the two changes of political regime affected the perpetuation of Orthodox church music and, in particular, music composition in the spirit of the Byzantine tradition. We will see how, during the turbulent period of the first post-war decades, the measures taken by the new leadership of the country severely disrupted the church life and altered the direction of development of Romanian church music, which had gone through a long process of Romanianization that enabled the development of a valuable liturgical repertoire of Romanian specificity. However, the period of stagnation that characterised the years of totalitarianism was fully compensated for in the last decade of the $20^{\text {th }}$ century by the revival of church music, due to the few preservers of the tradition, who also contributed to the formation of new generations of musicians and theologians specialized in this field.

We should point out that when we refer to psaltic creation we will not take into consideration the works included in the category of "standardized" church music, written in double notation, limiting ourselves instead only to those written in the authentic Byzantine style, in neumatic notation.

\section{The political regimes in Romania in the second half of the $20^{\text {th }}$ century - summary overview}

It is difficult to draw precise lines of demarcation when it comes to events whose significance can be fully understood only in a broader context, which can enhance their meanings. This is also the case of the first change of political regime in post-war Romania, which took place just a few years before the middle of the $20^{\text {th }}$ century; that is why it is imperative to dwell on the events that preceded the

\footnotetext{
1 Elena Chircev, Romanian Music of Byzantine Tradition Between 1918 and 2018, in Artes. Journal of Musicology, vol. 19-20, Iași, 2019.

2 Nicolae Gheorghiță, Cercetările de muzicologie bizantină în România totalitară [Byzantine Musicology Research in Totalitarian Romania], in "Muzica" journal, No. 7, 2015.

${ }^{3}$ See our works: The Byzantine Musical Tradition at Present Times. St. John the New from Neamt by Archd. dr. Sebastian Barbu-Bucur. In the journal Arta. (Arte audiovizuale), Elam Poligraf, Chișinău, 2010 and Tradition and Modernity in Current Psaltic Music. Vespers Hymns by Archdeacon Ph.D. Sebastian Barbu-Bucur, in Musicology Papers, vol. XXVI No. 2, MediaMusica, Cluj-Napoca, 2012.
} 
proclamation of the Romanian People's Republic, in 1947, though not before recalling a few historical data regarding the Romanian state.

Established as a state in 1859, through the unification of Moldova and Wallachia, Romania proclaimed its independence after the war won in 1877, and in 1881 was established as a kingdom with the coronation of King Carol I (who had been ruling the state since 1866). 1918 was the year of the Great Union, when the kingdom also incorporated the territories of Transylvania, Bessarabia and Bucovina, inhabited by Romanians. The reunited Romania continued to prosper and assert itself on a European level, overcoming the difficulties of World War I under the leadership of King Ferdinand I (1865-1827), crowned King of Greater Romania in 1922, at Alba Iulia. Following a dynastic crisis, he was succeeded by his nephew Michael (1921-2017), whose reign was interrupted due to the return of his father, King Carol II, to the country, who took over the reign of the state and ruled between 1930 and 1940. The periods of King Michael I's reign were: July 20, 1927 - June 8, 1930 and September 6, 1940 - December 30, 1947.

A moment of major importance during the reign of King Michael I was the "return of weapons", i.e. the denunciation of the treaty with Germany and the continuation of the war alongside the Western allies. The arrest of Marshal Ion Antonescu put an end to the military dictatorship imposed by him in 1940 and ended the war against the Soviet Union, in 1944. However, the historical events related to the coup d'etat of August 23, 1944, initiated by King Michael I, were distorted by the communists, who took full credit for the unfolding of the events ${ }^{1}$, so that August 23 later became the national day of the communist state. The historians who were loyal to the regime considered that this date marked the beginning of the "anti-fascist and anti-imperialist revolution", a name transformed by dictator Nicolae Ceaușescu into the "Revolution of Social, National, Antifascist and Anti-Imperialist Liberation". Although Romania was still a kingdom at the end of the Second World War, the transformation into a communist state began soon after the hostilities ended and gained momentum especially after March 6, 1945, when a self-titled government of "wide democratic concentration" was installed under the leadership of Ph.D. Petru Groza, which included members from the most diverse political groups (historical parties included) and, of course, communists and their supporters. The influence of the communists, who, in fact, were applying the decisions taken in Moscow regarding the taking over of the political power, led to the forced abdication of King Michael I on December 30, 1947, the abrogation of the 1923 constitution and the proclamation of the Romanian People's Republic - the new state in which the communist dictatorship had been established.

${ }^{1}$ Dinu C. Giurescu, România în Al Doilea Război Mondial [Romania in the Second World War], Editura ALL EDUCATIONAL, Bucharest, 1999, pp. 239-240. 
For more than 40 years, Romania remained in the Eastern European block, dependent on the U.S.S.R. The history of the events that led to the transformation of the kingdom into the socialist country was constantly distorted, the role of the communists and their sacrifices for the welfare of the people being exacerbated and contributing to the indoctrination of generations of children and young people, as the witnesses of the events were disappearing in communist prisons or were reduced to silence through blackmail and terror.

The proclamation of the republic was immediately followed by a period of transition, in which delation and the injustices of the "purification commissions" dealt a heavy blow to the clergy, while the censorship cut off any creative manifestation related to the sacred. The ideological offensive against the clergy continued even after the end of the Stalinist period, and the hopes generated by the changes that occurred after the death of Gheorghe Gheorghiu-Dej (1965), the party leader in the post-war period, were soon shattered, because the countless and expensive state visits of the Ceaușescus (about 2501) were opportunities for the "supreme ruler" to get in touch with the way of life and specific manifestations of the communist dictatorships from countries such as the People's Republic of China and the Democratic Republic of Korea (where he was received with a grand welcome ceremony during the four state visits). Following the Asian model, Nicolae Ceaușescu established a dictatorship in which the daily motto was "building up the multilaterally developed socialist society", and the cultural life was marked by the 17 theses (proposals) formulated by the leader during the speech delivered in July $1971^{2}$, according to which ideology would prevail in front of the aesthetic and culture would return to its role as a propaganda tool of the communist party.

The quality of the Romanian people's daily life continued to deteriorate during the $8^{\text {th }}$ and $9^{\text {th }}$ decades, in the context of the austerity regime imposed by the economic policy of the state, which had to pay huge debts and had engaged in grandiose construction projects (such as the People's House, currently the Palace of Parliament). The leader's cult of personality and megalomania, the growing role

\footnotetext{
${ }^{1}$ Cristina Păiușan, Narcis Dorin Ion, Mihai Retegan, Regimul comunist în România - O cronologie politică (1945-1989) [The Communist Regime in Romania - A Political Chronology (1945-1989)], Tritonic, Bucharest, 2002.

2 In 1971, Ceaușescu paid state visits to the People's Republic of China, North Korea, North Vietnam and Mongolia. Their consequence was the speech he delivered before the Executive Committee of the People's Communist Party on July 6, 1971, which brought significant changes in culture. The text was entitled Proposals of measures aimed at enhancing the political-ideological activity, of Marxist-Leninist education of the Party members and the entire working people and was published in November 1971 under the title Exposition regarding the RCP programme for improving ideological activity, raising the general level of knowledge and socialist education of the masses, in order to arrange relations in our society on the basis of the principles of socialist and communist ethics and equity. See Adrian Cioroianu, Pe umerii lui Marx. O introducere în istoria comunismului românesc [On Marx's Shoulders: An Introduction in the History of Romanian Communism], Curtea veche, Bucharest, 2005, p. 489.
} 
played in the society by the political police - the State Security -along with the events that happened in other countries of the Eastern Bloc contributed to the triggering of the December 1989 Revolution and to the restoration of the democratic regime in Romania.

\section{Church music "before" and "after" 1947 or how the church chant can survive in the atheist state}

In 1947, when the Romanian People's Republic was proclaimed, the church music of Byzantine tradition had already had a long and rich history, attested by numerous old manuscripts, by church chant collections printed in the $19^{\text {th }}$ century and by the contribution of numerous chanters who had perpetuated the style of the Byzantine chant throughout the centuries, with some of them composing their own works that resonated in the parish and monastery churches.

We must not forget that, in fact, the history of church music in the Romanian space is linked to the early presence of the Christians on the territory of today's Romania, part of it being "evangelized by an apprentice of our Saviour Jesus Christ, Saint Andrew the Apostle"1, the evidence claiming that "Romanian Christianity is of apostolic origin" 2 (our translation). The canonical dependency on the Patriarchate of Constantinople of the bishopric of Tomis, attested in the fourth century A.D. ${ }^{3}$ and the existence in the $6^{\text {th }}$ century of the Justiniana Prima Archbishopric ${ }^{4}$, which also had jurisdiction over the territories at the north of the Danube, explains the early placement of the proto-Romanian Christians in the area where the Eastern rite dominated and, subsequently, the use and perpetuation of Byzantine music throughout the medieval period.

The first original contributions to the body of Byzantine music occurred with the administrative organization of the Church, through the establishment of the first metropolitan sees in the territories inhabited by Romanians, in the $14^{\text {th }}$ century ${ }^{5}$. We certainly refer here to Pripelele [Pripela] by Filotei the Monk from the Cozia Monastery ${ }^{6}$, the small troparia composed by the chancellor of the

${ }^{1}$ Mircea Păcurariu, Istoria Bisericii Ortodoxe Române [The History of the Romanian Orthodox Church], vol. I, 2nd edition, Bucharest, Editura Institutului Biblic și de Misiune Al Bisericii Ortodoxe Române, 1992, p. 64.

2 Ibidem.

${ }^{3}$ Idem, p. 143.

${ }^{4}$ Vasile Vasile, Istoria muzicii bizantine și evoluția ei în spiritualitatea românească [The History of Byzantine Music and Its Evolution in the Romanian Spirituality], vol. II, Editura Interprint, Bucharest, 1997, p. 4.

${ }_{5}$ The Metropolitan See of Wallachia was founded in 1359, and that of Moldova in 1401.

${ }^{6}$ See Gheorghe Ciobanu, Pripelele lui Filotei monahul [Pripela of Filothei the Monk] in Studii de etnomuzicologie și bizantinologie [Ethnomusicology and Byzantinology Studies], vol. II, Editura Muzicală, Bucharest, 1979; Gheorghe C. Ionescu, Filothei the Monk of Cozia (14th-15th c.) Pripelele după Polieleu [Pripela after Polyeleos], in Gheorghe C. Ionescu, Studii de muzicologie și bizantinologie, 
Wallachian Voivode Mircea the Elder, also sung in the Slavic space; or, a little later, to the 186 chants of Evstatie Protopsaltes of Putna and to those composed by Theodosie Zotica and Dometian the Vlach, whose affiliation to the same music school has been proven ${ }^{1}$. While these works were written in the Slavonic and Greek languages, there are also records dating from the beginning of the $18^{\text {th }}$ century of the first church chants composed directly on Romanian text by Filotei sin Agăi Jipei², during the reign of Constantin Brâncoveanu (1654-1714). In the $19^{\text {th }}$ century, a whole plethora of talented chanters asserted themselves through their works, whether translations from Greek or own compositions: Macarie the Hieromonk (1770-1836), Ghelasie the Bessarabian (?-1851), Anton Pann (?1796-1854), Dimitrie Suceveanu (1816-1898) or Ștefanache Popescu (1824-1911).

Although the church music composed in the $20^{\text {th }}$ century was mainly harmonic in character - a fact that determined Father Nicu Moldoveanu to state that "... quantitatively speaking, the $20^{\text {th }}$ century is somewhat poorer than the previous one..." 3 -, the monody of Byzantine tradition continued to develop in the Romanian space in the areas outside the Carpathian chain (Moldova, Wallachia, Oltenia $)^{4}$, giving rise to a psaltic repertoire of Romanian specificity. This repertoire was also enriched by the chanter-composers of the first half of the century; standing out among them (through the quantity and quality of their works) were Theodor Stupcanu (1861-1926), Atanasie Dincă (1896-1973), Anton Uncu (1908-1976) and Victor Ojog (1909-1973)5. However, the leading personality of the

[Ethnomusicology and Byzantinology Studies], publisher not identified, Bucharest, 1997; David Pancza (2013) The Filotean Pripela: Analysis of Text and Melody. In Unity and Variety in Orthodox Music: Theory and Practice. Proceedings of the Fourth International Conference on Orthodox Church Music. University of Joensuu, Finland, 6-12 June 2011. Moody I. and Takala-Roszczenko M. (ed.) Joensuu: The International Society of Orthodox Church Music, 2013, pp. 472-476.

${ }^{1}$ See: Titus Moisescu, Putna - un puternic centru de cultură muzicală medievală românească [Putna - A Powerful Centre of Romanian Medieval Musical Culture], in T. Moisescu, Muzica bizantină în spațiul cultural românesc [Byzantine Music in the Romanian Cultural Space], Editura Muzicală, Bucharest, 1996; Anne E. Pennington, Muzica în Moldova Medievală (secolele XV-XVI) [Music in Medieval Moldova $\left(15^{\text {th }}-16^{\text {th }}\right.$ c.) ], bilingual edition supervised by Titus Moisescu, Editura Muzicală, Bucharest, 1985; Dimitri E. Conomos, Mănăstirea Putna şi tradiția muzicală a Moldovei în secolul al XVI-lea [The Putna Monastery and the Musical Tradition of Moldova in the $16^{\text {th }}$ Century], in the bilingual volume Muzica in Moldova Medievală (secolele XV-XVI) [Music in Medieval Moldova (15 th-16 $6^{\text {th }}$ c.)], op. cit., pp. 260-267.

2 See: Archd. Ph.D. Sebastian Barbu-Bucur, Filothei sin Agăi Jipei - Psaltichie rumănească [Filothei sin Agăi Jipei - Romanian Psalm Book], vol. I, Catavasier [Book of Katavasias], Editura Muzicală, Bucharest, 1981. ${ }^{3}$ Nicu Moldoveanu, Istoria muzicii bisericești la români [The History of Church Music in Romania], Basilica, Bucharest, 2010, p. 123.

${ }^{4}$ In Transylvania and Banat, which were part of the Austro-Hungarian Empire, the church chant circulated orally for a long time, being notated on the staff, in various collections of the end of the $19^{\text {th }}$ century and beginning of the $20^{\text {th }}$ century. See, in this regard, our book entitled Muzica românească de tradiție bizantină între neume și portativ [Romanian Music of Byzantine Tradition Between Neumes and Staves], vol. I-II, Risoprint, Cluj-Napoca, 2013.

${ }^{5}$ Other psaltic music composers of the first half of the $20^{\text {th }}$ century were: Irinarh Vântul (?1860-1940?), Theodor Stupcanu (1861-1926), Damian S. Rânzescu (1862-1948), Nicolae Severeanu (1864-1941), 
period was Ion Popescu-Pasărea (1871-1943), who made a decisive contribution to the completion of the process of Romanianization of church chants ${ }^{1}$.

Although there were many who composed church music, preserving the characteristics of Byzantine music and using neumatic notation, what characterizes the first half of the $20^{\text {th }}$ century is the concern for preserving the traditional chant and for improving and refining the liturgical repertoire that had gone through the process of translation of the Greek text and of adaptation of the songs to the Romanian text. There were numerous republications of the collections published in the previous century and many works composed by Macarie, Anton Pann and Dimitrie Suceveanu were included in various anthologies by the chanters of the time. At the same time, the repertoire sung during the Divine Liturgy was enriched with new works written for the harmonic choir.

The changes that occurred in the political landscape in the post-war period brought about a break with everything that the Church had represented in the spiritual life of the Romanian people, and the impact on musical creation was so great that in the next four decades very few psaltic compositions were published and made available to those who still had the courage to defy the Securitate and to sing them in churches.

In fact, as Archd. Ph.D. Sebastian Barbu-Bucur and Pr. Alexie Buzera found in 1999 - on the occasion of the republication of Victor Ojog's Anastasimatar [Anastasimatarion] -, Romanian church music went through a serious crisis in the middle of the $20^{\text {th }}$ century ${ }^{2}$. The new cultural system imposed by the Soviet power and meant to contribute to the formation of the "new man" excluded many universal values of literature, art and music, promoting atheism instead. Therefore, just a few months after the proclamation of the Romanian People's Republic, the Ministry of Cults published the Decree No. 177 in the Official Gazette No. 178

Gherontie Nicolau (1867-1948), Amfilohie Iordănescu (1870-1937), Bishop Evghenie Humulescu-Piteșteanu (1870-1931), Filotei Moroșanu-Hanganu (1876-1951), Dimitrie-Gheorghe Cutava (1883-1974), Vasile Coman (19 $19^{\text {th }}-20^{\text {th }}$ c.), Gheorghe Cotenescu (1886-1965), Marin Predescu (1891-1979), Elefterie Marinescu (1892-1985), Ion Mardale (1895-1971), Vasile Sava (1896-1985); for details on their works see our paper Romanian Music of Byzantine Tradition Between 1918 and 2018, op. cit.

${ }^{1}$ Sebastian Barbu-Bucur identifies four stages in the process of "Romanianization" of church chants: "1) from their appearance - at least from Coresi - until the late part of the $17^{\text {th }}$ century, when the chant in the Romanian language was «oral», without Byzantine neumes; 2) from the last decades of the 17 th century to the Chrysantine reform; 3) to Macarie and Anton Pann; 4) from Dimitrie Suceveanu, Neagu Ionescu, Ştefanache Popescu etc. to Popescu-Pasărea, who was the last important contributor to the process of Romanianization of ecclesiastical songs", Archdeacon Ph.D. Sebastian Barbu-Bucur, Cultura muzicală de tradiţie bizantină pe teritoriul României în secolul XVIII şi începutul secolului XIX şi aportul original al culturii autohtone [The Musical Culture of Byzantine Tradition Across the Romanian Territory in the $18^{\text {th }}$ Century and at the Beginning of the $19^{\text {th }}$ Century and the Original Contribution of the Local Culture], Editura Muzicală, Bucharest, 1989, p. 95 (our translation).

${ }^{2}$ In the preface to the book they wrote: "Psaltic music has gone through several crises (...) from time to time, but none has equalled the crisis of the last 50 years", Victor Ojog, Anastasimatar [Anastasimatarion], Trinitas, Iași, 1999, p. V (our translation). 
of August 4, 1948, regarding the general regime of religious denominations. Although Article 1 stated that "the State guarantees the freedom of conscience and religions throughout the Romanian People's Republic" ${ }^{\prime 1}$, the activity of the religious denominations was subject to their recognition by the state, through the Great National Assembly, which could also withdraw this recognition ${ }^{2}$. The same decree consented to the interference of the state in the activity of the Church, which was controlled and supervised by the government and by the Great National Assembly ${ }^{3}$. The same decree abolished numerous higher education and pre-university units; thus, according to Article 49, for the training of the clergy, the orthodox denomination was allowed to have two theological institutes of university rank 4 . Consequently, the Faculty of Theology in Bucharest was transformed into a Theological Institute of university rank, while a similar institution was also established in Sibiu. For the pre-university education, only six Theological Seminaries were left after 19485, with more than 40 schools of church singers being abolished, although before that year such institutions had operated in all the county capital cities, in various other Romanian cities and attached to numerous monasteries.

One of the fundamental changes in religious education, with serious consequences for the training of specialists in the musical field, was the abolition of the Religious Music Department of the Royal Academy of Music and Dramatic Art in Bucharest. This section originated in the Academy of Religious Music established in 1928 by Patriarch Miron Cristea (1868-1939) and attached to the

${ }_{1}^{1}$ Decree No. 177/1948, see: Legislative portal, http://legislatie.just.ro/Public/DetaliiDocumentAfis/47, accessed: 20 March, 2019.

2 See Article 13 of Decree 177: "The organization and operation of any religious denomination are subject to recognition by a decree issued by the Presidium of the Great National Assembly, at the proposal of the Government, following the recommendation of the minister of cults. In well-motivated cases, recognition may be withdrawn in like manner".

http://legislatie.just.ro/Public/DetaliiDocumentAfis/47, accessed: 20 March, 2019.

${ }^{3}$ See, for example, Article 21: "The heads of the church, as well as the metropolitans, archbishops, bishops, superintendents, apostolic administrators, vicar-administrators and others having similar functions, elected or appointed according to the organizing statutes of the respective denominations, will be recognized solely subject to approval by the Presidium of the Great National Assembly, given by decree, at the proposal of the Government, following the recommendation of the minister of cults.", Article 24: "The religious denominations may hold congresses or general assemblies subject to approval by the Ministry of Cults, and local conferences and meetings (eparchial, parish assemblies), subject to approval by the respective local authorities." or Article 56: "All the religious denominations are due to submit their organizational statute in accordance with the provisions of the present law, for approval by the Ministry of Cults, within 3 months from the date of publication of this law. Statute approval is given by decree of the Presidium of the Great National Assembly, at the proposal of the Minister of Cults" (our translation). http://legislatie.just.ro/Public/DetaliiDocumentAfis/47, accessed: 20 March, 2019.

${ }^{4}$ Article 49, Decree No. 177/1948, Legislative portal, http://legislatie.just.ro/Public/DetaliiDocumentAfis/47, accessed: 20 March, 2019.

${ }^{5}$ These were located in the cities of Bucharest, Buzău, Craiova, Neamț, Cluj and Caransebeș. 
Romanian Patriarchate. The institution, whose rector since 1935 was the priest Ioan D. Petrescu (1884-1970), merged with the Royal Academy of Music, in 1941.

Among the graduates of the Academy of Religious Music of Bucharest we find important names related to the church music of the second half of the 20 ${ }^{\text {th }}$ century, such as Archimandrite Victor Ojog (1909-1973), Chiril Popescu (1897-1992), priest Anton V. Uncu (1908-1976), who compiled collections of church chants and composed church music.

Father Ioan D. Petrescu was a professor of Gregorian chant and Byzantine music palaeography at the Religious Music Department of the Royal Academy, until his retirement in 1948, when the department was abolished. Along with this vanished the aspirations of those who had hoped that the institution was going to play an important role. In this regard, we quote the great chanter Ion Popescu-Pasărea who, in 1939, wrote:

"Following the turmoil and polemics over the subject of our psaltic church music, its situation has been clarified by the establishment of the Academy of Religious Music, at the request of His Beatitude Patriarch Miron Cristea. We hope that in this institution, psaltic music will be studied in its authentic Byzantine (our emphasis) form, as well as in its various adaptations to the Romanian musical genius, made by our Church. Here, as in a laboratory, the church musical folklore material from all the Romanian provinces will be melted, to create a single type of church song for the Romanian Orthodox

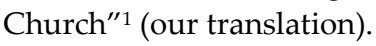

The desire to study church music "in its true Byzantine form" could no longer be fulfilled. The disappearance of the Religious Music Department was prejudicial to the training of specialists in the field of Byzantine and Gregorian music, so that, for decades, in musical higher education, the field of music palaeography was completely ignored, while the continuation of the research on the Byzantine musical manuscripts was left to the personal initiatives of some of those who were familiarized with Father Petrescu's activity of research and promotion of Byzantine music through research, conferences and musical performances. His assiduous work of investigating the old musical manuscripts remained in the shadows for a long time during the post-war period, although musicologist Titus Moisescu rightly considered that “... he was one of the most important theoreticians of old Byzantine music, who founded the Romanian School of musical Byzantinology. [...] His works will lie at the basis of all the research in the Byzantine field"2 (our translation).

\footnotetext{
${ }^{1}$ Ion Popescu-Pasărea, Muzica bisericească [Church Music], in Petre Nițulescu (ed.), Muzica românească de azi. Cartea sindicatului artiștilor instrumentiști din România [Romanian Music Today. The Book of the Trade Union of the Romanian Instrumental Artists], Institutul de Arte Grafica MARVA. S.A.R., Bucharest, 1939, p. 602.

2 Idem, p. 87.
} 
Relevant for the attitude of the official bodies regarding church music was the situation of his volume entitled Études de paléographie musicale ${ }^{1}$. In 1958, the 1118-page typed manuscript including numerous examples with transcripts from musical manuscripts of the $11^{\text {th }}$ to the $18^{\text {th }}$ centuries was submitted to the Union of Composers and Musicologists for publication. Considered as "a notable Romanian contribution to world research" 2 , with recommendations from the International Union of Academies and from Academician Emil Condurachi, director of the Archaeology Institute of the Romanian Academy3, the work was published only in 1967.

It is not surprising that Father I. D. Petrescu's work, loaded with examples that were nothing but church songs, did not receive the approval for publication in 1958. It was precisely then that the party's leading bodies were preparing new reprisals against those who served in churches and lived in monasteries. The following year they issued the Decree No. 410, which affected monastic life to a tremendous extent. As a matter of fact, during all the years that followed the change of regime, the State Security had carefully supervised the activity carried out in the monastic settlements, for the following two main reasons:

“... the danger it could pose from a political point of view (supporting the anti-communist resistance movement, sheltering people who were hostile to the regime) and from a spiritual one, with the monasteries being true centres where the authentic faith was preserved, which could not be accepted by an atheist political regime. For this reason, the State Security documents speak with contempt of the «black army of monks and nuns» who had to be suppressed by all means" ${ }^{4}$ (our translation).

The danger represented by this "army" was reassessed after the Hungarian revolution of 1956, considering that "... a very large number of «hostile elements» took refuge in monasticism" 5 . Therefore, in 1958, the Department of Cults issued a new regulation regarding the monasteries - with retroactive character -, which restricted the right of certain persons to enter monastic life; alongside the minors

${ }^{1}$ Ioan D. Petrescu, Études de paléographie musicale, Editura Muzicală, Bucharest, 1967.

2 Titus Moisescu, Preotul Ioan D. Petrescu-Visarion. Ctitor al Școlii românești de muzică bizantină [Priest Ioan D. Petrescu-Visarion. Founder of the Romanian School of Byzantine Music], in Monodia bizantină în gândirea unor muzicieni români [The Byzantine Monody in the Conception of Romanian Musicians], Editura Muzicală, Bucharest, 1999, p. 61.

${ }^{3}$ All the details related to the publication of this volume are provided by musicologist Titus Moisescu, who was a book editor at Editura Muzicală [Musical Publishing House], in the extensive study dedicated to priest Ioan D. Petrescu, mentioned above, Preotul Ioan D. Petrescu-Visarion... [Priest Ioan D. Petrescu-Visarion...], ed. cit., pp. 60-66.

${ }^{4}$ George Enache, Decretul 410/1959. Un scurt bilanț la 50 de ani de la adoptare [Decree 410/1959. A Brief Report 50 Years after Its Adoption], Ziarul Lumina, on-line, at:

https://ziarullumina.ro/documentar/decretul-410-1959-un-scurt-bilant-la-50-de-ani-de-la-adoptare37899.html

${ }^{5}$ Ibidem. 
and those who had less than seven elementary grades, the regulation included the "counter-revolutionary elements", as well as those known for their "hostile manifestations" against the communist regime ${ }^{1}$. Decree No. 410 supplemented the 1948 article with an article 71 which had the following content:

\begin{abstract}
"Monasticism can operate only in authorized monasteries of legally recognized denominations. Authorization for the functioning of the monasteries is given by the Department of Cults. The graduates of the clergy training schools can enter monasticism at any age, provided they have completed their military service. Other persons may be admitted to monasticism, i.e. men over 55 and women over 50 years of age, provided they waive their salary or pension rights and are not married or have obligations under the Family Code. Whenever required, the Department of Cults may authorize certain monks to hold church functions and receive the appropriate salary" ${ }^{\prime \prime}$.
\end{abstract}

Following this decree and the aforementioned regulation, a large campaign was launched to verify the inhabitants of the monasteries and about 4750 persons were removed from monasticism ${ }^{3}$, especially young ones. For this reason, about 100 monasteries were abolished $^{4}$ and the buildings received other destinations. Those who refused to give up monastic life were arrested or sentenced to house arrest. Anyway, they were all watched by the State Security for a long time and forced to integrate into society and find employment, as "... a proof that they have become "productive elements» who will contribute to the building of socialism" 5 (our translation).

An eloquent example for the reprisals to which the monks were subjected is that of Archimandrite Victor Ojog (1909-1973), teacher, composer and chanter, prized for his activity and works ${ }^{6}$. His destiny was linked to the Neamț Monastery,

\title{
1 Ibidem.
}

2 Ibidem.

${ }^{3}$ Ibidem.

${ }^{4}$ In the above-quoted article, George Enache wrote: "According to some partial figures from the documents of the former Securitate, on January 1, 1959 there were 224 Orthodox monasteries in Romania, while in October 1959 (i.e. after the application of the provisions of the monastic regulation), 194 monasteries were inventoried. By March 31, 1960, only 132 monasteries were still operating. In the end, the Securitate estimated that 92 monasteries had been shut down." (our translation) In his book Holocaustul roșu sau crimele în cifre ale comunismului internațional [The Red Holocaust or the Crimes of International Communism in Numbers], Editura IRECSON, Bucharest, 2008, F. Mătrescu estimated that over 100 monasteries had been abolished.

${ }^{5}$ George Enache, op. cit.

6 The Anastasimatar [Anastasimatarion] by Victor Ojog (the so-called "antologhion" [anthology] mentioned by Dudu Velicu), printed in 1943, was appreciated for the preservation of the traditional style of the psaltic chant by Archd. Ph.D. Sebastian Barbu-Bucur and Priest Assoc. Prof. Ph.D. Alexie Buzera, who republished the book in 1999 and wrote in the preface (pp. V-VI) that this is "... the work that incorporates and crystallizes the experience of two centuries of Romanian psaltic chant..." (our emphasis and translation), while Pr. Prof. Ph.D. Nicu Moldoveanu, believes that "all the chants are very 
where he entered at the age of 13 and took the veil in 1932, when he was also ordained deacon. He completed his training at the school of church singers in Iași and at the Academy of Religious Music, where he stood out "among the best students in Professor Ion Popescu-Pasărea's class" ${ }^{1}$ (our translation). Then he was a church music teacher at the school of church singers and at the monastic Theological Seminary of the Neamț Monastery (1939-1949). He was one of the victims of Decree 410, being expelled from monastic life in 1959, although his supervision had begun long before. According to Dudu Velicu's ${ }^{2}$ daily notes, Archimandrite Victor Ojog (incorrectly written Ojoga) had been arrested on January 30, 1948:

"At the Neamț Monastery, the police arrested several monks, among whom also Archimandrite Ojoga, administrator and professor of church music, author of an anthology related to the weapons found there (mine throwers, machine guns, etc.). According to others, Victor Ojoga was arrested for sabotage, because he did not give the due share of wheat to the state, on behalf of the monastery"3 (our translation).

After his removal from the monastery, Archimandrite Victor Ojog settled in the city of Piatra Neamț and, in order to prove that his re-education process was ongoing, he had to take up a modest job (bus conductor) at the local transport company. The beloved psaltic music composer and teacher ended up humiliated and ill, in a precarious material situation ${ }^{4}$.

From Dudu Velicu's notes it also follows that measures were constantly being taken against the church servants; for example, in February 1949, the number of church singers was drastically reduced ${ }^{5}$, their role in the services being taken over by one of the priests, if there were two servants of the altar. In fact, the communist government was constantly concerned with re-educating the Church's servants and looking for ways to exclude them from monastic life. On June 10, 1949, Dudu Velicu wrote: "In clerical circles it is said that the Government will take

well written in the traditional spirit. Many of them lied at the basis of the standardized chants of the second half of the $20^{\text {th }}$ century". Nicu Moldoveanu, Istoria muzicii bisericești la români [The History of Church Music in Romania], Basilica, Bucharest, 2010, p. 185 (our translation).

${ }^{1}$ Gheorghe C. Ionescu, Muzica bizantină în România. Dicționar cronologic [Byzantine Music in Romania. Chronological Dictionary], Sagittarius, Bucharest, 2003, p. 426.

${ }^{2}$ Dudu Velicu, Biserica Ortodoxă în anii regimului comunist. Însemnări zilnice II, 1948-1959 [The Orthodox Church in the Years of the Communist Regime. Daily Notes II, 1948-1959], edition supervised by Alina Tudor-Pavelescu and Șerban Marin, Arhivele Naționale ale României, Bucharest, 2005.

${ }^{3}$ Dudu Velicu, op. cit., p. 8.

${ }^{4}$ For details, see Gheorghe C. Ionescu, Muzica bizantină în România... [Byzantine Music in Romania...], op. cit., p. 427 and Pr. Prof. Ph.D. Nicu Moldoveanu, op. cit., pp. 183-184.

5 Dudu Velicu notes: "As regards the singers, only 120 remained in the Metropolitan See of Ungro-Wallachia, namely only where there was only one priest in a church. In the churches with two or more priests, both singers were discharged, while the priests would take turns replacing the singer", op. cit., p. 140 (our translation). 
a series of measures, which will regulate the situation of the monks who are fit for work and who should no longer hibernate around the monasteries (our emphasis and translation)." 1

The reduction in the number of theological seminaries was meant to discourage the young people who aspired to a life in prayer and meditation; the measure also affected the teachers who worked in these institutions, priests and monks, who, in their turn, had to contribute to the building of communism by doing physical work in factories and plants. Another monk-musician who suffered because of this measure was Archd. Ph.D. Sebastian Barbu-Bucur (1930-2015), prolific composer and outstanding personality in the field of Byzantine musicology. After graduating from the Theological Institute in Bucharest, in 1957, he was appointed music teacher and choir conductor at the Theological Seminary of the Neamț Monastery. The dissolution of the seminary forced him to take up a job "in the production industry".

Years later, the distinguished father recalled that period in an interview:

"... I became a music teacher at the best theological Seminary in the country, at the Neamț Monastery, a seminary directly patronized by Patriarch Justinian himself. The peace and satisfaction of the accomplishment did not last long. The autumn of 1959 was going to be a dramatic one. The flower of monasticism was crushed by the provisions of Decree 410, whereby 7500 monks and nuns were expelled and had to go each their own way. And so I was left useless, but I stubbornly refused to work as a factory worker, as the decree required, and knocked at the gates of the Conservatory. I was kicked out of there too, for one year, because of three crosses that I gave to my colleagues" $^{\prime 2}$ (our translation).

Not only those who came from the monastic environment were affected by the measures taken constantly during the $5^{\text {th }}$ and $6^{\text {th }}$ decades of the last century, but also the young people who studied theology. One of those who had a lot to suffer in the early 1960s is father Florin Bucescu (b. 1936), a theologian and musician who was highly knowledgeable in the field of the psaltic chant. He was trained in the same prestigious Theological Seminary of the Neamț Monastery, graduated from the Theological Institute in Bucharest, in 1957, and immediately enrolled in the doctoral program at the same institution; however, for political reasons, he was forced to discontinue his doctoral studies in 1960. Like Archdeacon Ph.D. Sebastian Barbu-Bucur, he went to a secular music school, but it was only two years later that he was allowed to enrol at the "George Enescu" Conservatory

${ }^{1}$ Idem, p. 159.

2 Elena Chircev, Mereu neînfrânt! [Always Invincible!], Interview with Archd. Ph.D. Sebastian Barbu-Bucur. Tabor. Revistă lunară de cultură şi spiritualitate românească [Tabor. Monthly Journal of Romanian Culture and Spirituality], the Metropolitan See of Cluj, Alba, Crişana and Maramureş, Cluj-Napoca, No. 1, 2010, pp. 77-84. 
of Music in Iași. He then taught music at the C. Negruzzi High School in Iași (1967-1991) and resumed his doctoral studies, this time in the field of Byzantine music, at the National University of Music in Bucharest, under the supervision of Archd. Ph.D., Sebastian Barbu-Bucur ${ }^{1}$.

All the measures taken by the leadership of the communist party between 1947 and 1959 had a profound impact on church life as a whole and on church music in particular. The reduction in the number of church singers, the lack of educational establishments, the purges that reduced the number of qualified teachers who were very knowledgeable in the field the psaltic tradition, were likely to affect the preservation of tradition and the authentic chant style.

Meanwhile, in order to cope with the dramatic situation in which the Orthodox denomination found itself, the heads of the Romanian Orthodox Church were forced to develop a strategy to ensure optimal conditions for the performance of the services, and the solution they found was the so-called "standardization" of the church chant repertoire. That is, the introduction of a unique, simplified version of the psaltic chant, which would eliminate the regional variants of the church chant from the areas outside the Carpathian chain and, at the same time, ensure an active participation of the believers in the services, by jointly singing the liturgical responses. In order to help the clergy and the believers from the areas where church music had been notated on the staff for decades, the standardized version of the repertoire was rendered in simultaneous notation, with neumes and notes written on the staff. At the same time, the solution adopted by the leaders of the Orthodox Church, by imposing the "standardized" repertoire, which could also be sung by the believers, had another motivation; the "joint singing" of all the participants in the religious service could make up for the shortage of church singers as a result of the disappearance of the schools in which they were trained and of the reduction in the number of service officiants.

The decision was taken at the session of the Holy Synod of June 1952, on which occasion His Beatitude Patriarch Justinian Marina (1901-1977) showed that:

“... it is time to put an end to regionalist church music and it is absolutely necessary that in Transylvania, Banat and in all the parts of the country we abide by the traditional psaltic music, so that one day, by standardizing the church chants, a believer from Dobrogea will be at any time able to take active part in the responses to the Divine Liturgy in a church in Maramureş, or a believer from Banat will be able to do the same in a church in Moldova." (our translation $)^{2}$

\footnotetext{
${ }^{1}$ He completed his doctoral studies with the thesis Cântarea psaltică în manuscrisele moldoveneşti din secolul al XIX-lea [The Psaltic Chant in the Moldavian Manuscripts of the 19th Century].

${ }^{2}$ Lucrările Sfântului Sinod... [The Meeting of the Holy Synod...], 1951, p. 617.
} 
The decision of the Holy Synod had been prepared in the previous years through the publication of a collection entitled Cântări liturgice omofone și cântări la Cateheze pe ambele semiografii suprapuse [Homophonic Liturgical Chants and Catechetical Chants in Both Overlapped Notations] $]^{1}$, compiled by professors Nicolae Lungu (1900-1993) and Anton Uncu (1908-1976) from the University Theological Institute of Bucharest. The theoretical musical training of the future theologians was to be ensured by a theoretical work: Gramatica muzicii psaltice. Studiu comparat cu notația liniară [The Grammar of Psaltic Music. Comparative Study with Linear Notation] $]^{2}$. Both books had already been printed in 1951, and in 1953 and 1954 they were followed by the publication of Anastasimatarul uniformizat [The Standardized Anastasimatarion] ${ }^{3}$. Here is how the choice of the simultaneous notation is explained by the authors of the above-mentioned books:

“... our effort does not aim to [...] change or replace psaltic music, as, perhaps, it is believed by those who do not know the problem, but, on the contrary, to save and secure it, like an asset that is an integral part of our spiritual heritage. Anyone is free to use any of the two notations, which in this grammar are overlapped. What really counts is that the unparalleled beauty and charm of the psaltic chants be not distorted by misinterpretation and faulty performance, as is happening today at every step, because of the existing complicated and confusing psaltic grammars" ${ }^{\prime 4}$ (our translation).

The notation of psaltic music on the staff and the fact that, due to the political pressure, many of those who studied in theological seminaries continued their studies in conservatories during the turbulent period of the last five to six decades of the last century 5 , had as result the decades-long publication of the

${ }^{1}$ Nicolae Lungu, Anton Uncu, Cântări liturgice omofone și cântări la Cateheze pe ambele semiografii suprapuse [Homophonic Liturgical Chants and Catechetical Chants in Both Overlapped Notations], Editura Institutului Biblic și de Misiune al B.O.R., Bucharest, 1951.

2 Nicolae Lungu, Grigore Costea, Ion Croitoru, Gramatica muzicii psaltice. Studiu comparat cu notația liniară [The Grammar of Psaltic Music. Comparative Study with Linear Notation], Editura Institutului Biblic și de Misiune al B.O.R., Bucharest, 1951.

${ }^{3}$ Nicolae Lungu, Grigore Costea, Ion Croitoru, Anastasimatarul uniformizat. Vecernierul sau cântările vecerniei de sâmbătă seara ale celor opt glasuri bisericești [The Standardized Anastasimatarion. Chants for Saturday Evening Vespers in the Eight Tones], Editura Institutului Biblic și de Misiune al B.O.R., Bucharest, 1953. Nicolae Lungu, Ene Braniște, Grigore Costea, Anastasimatarul uniformizat II. Cântările utreniei de duminică dimineața ale celor opt glasuri bisericești urmate de Svetilnele Evangheliilor și ale Doxologiei Mari [The Standardized Anastasimatarion II. Chants for Sunday Morning Matins in the Eight Tones Followed by the Exapostilaria of the Gospels and of the Great Doxology], Editura Institutului Biblic și de Misiune al B.O.R., Bucharest, 1954.

${ }^{4}$ Nicolae Lungu, Grigore Costea, Ion Croitoru, Gramatica... [The Grammar...], ed. cit., pp. 8-9.

${ }^{5}$ Many musicians of the second half of the $20^{\text {th }}$ century were in this situation, and some of those who later paid attention to Byzantine music are: Victor Giuleanu, with Melodica bizantină [The Byzantine Melodics] (1981); Titus Moisescu with Prolegomene bizantine. Muzică bizantină în manuscrise și carte veche românească [Byzantine Prolegomena. Byzantine Music in Manuscripts and Old Romanian Books] (1985), both published by Editura Muzicală in Bucharest. 
anthologies of church songs in double notation, as well as the orientation towards choral composition. After the publication of the aforementioned volumes, Professor Nicolae Lungu continued to transcribe into staff notation the church songs that had been printed in simultaneous notation and had circulated in the Romanian churches; he also created numerous harmonizations of chants of the Divine Liturgy, Triodion, Pentecostarion, Lamentation etc. ${ }^{1}$ It was hoped that in this way psaltic music would be saved and that choral creation would not break away from tradition. This idea is formulated in the preface to Gramatica ... [The Grammar...], whose authors believe that the work will prevent the churches from: "... inappropriately peppering the choral repertoire heard today in our churches, and that we will be spared, especially of what must in no way happen, namely the disappearance of the psaltic chant and its replacement with another type of song, which has happened in other Orthodox Churches" 2 (our emphasis and translation).

Professor Nicolae Lungu's example was followed by some younger confrères. Priest Radu Antofie (1904-1987), conductor of the Episcopal Choir of Buzău, who had privately studied harmony and choral composition with Nicolae Lungu' ${ }^{3}$, composed two liturgies for mixed choir and different other liturgical hymns, but only a part of them were published in the journal "Glasul Bisericii" [The Voice of the Church]. The collections of church chants in double notation compiled by him remained in manuscript form - Noul Anastasimatar [The New Anastasimatarion], Cinci Slavoslovii [Five Great Doxologies], Slujba învierii [Service of the Resurrection], Cântări din Penticostar [Pentecostarion Chants] ${ }^{4}$.

Another servant of the Church who wrote psaltic music in double notation was Father Constantin Drăgușin (1931-2014), who had been trained at the seminaries in Râmnicu Vâlcea and Curtea de Argeș, as well as at the Theological Institutes in Sibiu and Bucharest. His works also remained in manuscript form until 1992: Tropar la Duminica Sfinților români [Troparion of the Sunday of the Romanian Saints], tone 3, Tropar pentru Sfântul Teodosie [Troparion of Saint Theodosius], tone 1 and Prea Curată Maică pururi Fecioară [Most Pure Mother, Ever Virgin Mary], tone 3 (on verses by Vasile Militaru) ${ }^{5}$. But his choral compositions dodged censorship and were printed in the journals "Biserica Ortodoxă Română" [The Romanian Orthodox Church], "Glasul Bisericii" [The Voice of the Church]

\footnotetext{
${ }^{1}$ See the complete list of works in Gheorghe C. Ionescu, Muzica bizantină în România [Byzantine Music in Romania], ed. cit., pp. 395-396.

2 Nicolae Lungu, Grigore Costea, Ion Croitoru, Gramatica... [The Grammar...], ed. cit., p. 9.

${ }^{3}$ Gheorghe C. Ionescu, Muzica bizantină în România [Byzantine Music in Romania], ed. cit., p. 403.

${ }^{4}$ Idem, p. 404.

${ }^{5}$ From among his compositions, Ectenia mare [The Great Ectenia], tone 1, p. 91, Antiphon I and Antiphon II, both in tone 1, were published in Cântările Sfintei Liturghii și alte cântări bisericești [The Chants of the Divine Liturgy and Other Church Chants], 1992, on pages 91, 92 and 93-95.
} 
and "Mitropolia Olteniei" [The Metropolitan See of Oltenia], starting with 19651; it is possible that this was aided by his prestige as a second conductor (1954-1972) and later first conductor (1984-2009) of the Choir of the Romanian Patriarchate.

If during the communist years, church choral creation was of prime concern among the composers dedicated to this branch, this was undoubtedly due to all those draconian measures taken by the communist leaders against the monks, priests and believers. Even those who met all the conditions required to compose psaltic music and had talent and the necessary training could only timidly manifest themselves creatively and their works most often remained in manuscript form. One of the chanter-musicians trained before the change of the political regime, a graduate of the Bucharest Music Conservatory (1928) and of the Academy of Religious Music (1932), who composed psaltic music preserved in manuscript form was Chiril Popescu (1897-1992). An esteemed church singer and teacher in various schools for church singers during the inter war period, he endured the rigours of the regime until his retirement (1960). Professor at the Theological Institute in Bucharest (1954-1955 and 1956-1960), he sang on the kliroses of several churches in Bucharest, until 19902. He collaborated with professor Nicolae Lungu on the publication of several works ${ }^{3}$ and published chants in simultaneous notation ${ }^{4}$. His few psaltic music compositions ${ }^{5}$ were preserved in manuscript form, but were probably sung by the chanter himself on the kliroses of the churches where he served. Because they are undated, we can only assume that the troparia and kontakia for the Saints whose relics are preserved in Curtea de Arges are linked to the period when he was a singer on the left kliros and protopsaltis at the Episcopal Cathedral of Curtea de Argeș (1917-1942). Posterity appreciates his works, as does Father Nicu Moldoveanu, who considers that "his style seems to be a synthesis of his predecessors Anton Pann, Macarie

1 See their list in Ionescu, Muzica bizantină în România [Byzantine Music in Romania], ed. cit., pp. 483-484.

${ }^{2}$ Gheorghe C. Ionescu, op. cit., p. 391.

${ }^{3}$ Cântări din slujbele Sfintelor taine și ale ierurgiilor principale: Botezul, Cununia, Te Deum-ul și Înmormântarea [Chants of the Service of the Holy Sacrements and of the Main Religious Services. Baptism, Marriage, Te Deum and Burial], Bucharest, 1964, in collaboration with Nicolae Lungu and Ene Braniște.

${ }^{4}$ For example: Cântările Penticostarului uniformizate, lucrare întregită cu slujba Înălțării Domnului și Pogorârii Duhului Sfânt [The Standardized Pentecostarion Chants, a Work Completed with the Liturgical Service of the Ascension of the Lord and the Descent of the Holy Spirit], in "Glasul Bisericii" [The Voice of the Church], Bucharest, Year XLVI (1986), No. 5, Sept.-Oct., in Anexă [Appendix] pp. I-XII.

${ }^{5}$ Cântări la Pavecernița Mare [Chants of the Great Compline], tone 8; Ceea ce ești mai cinstită [Thou the More Honourable], tones 5, 6, 7; Lumină lină [Gracious Light], in eight tones; Aliluia ce se cântă în Postul Mare [Hallelujah Chanted during Great Lent], in eight tones; Tropare și Condace [Troparia and Kontakia] for the Saints whose relics were or are preserved in Curtea de Argeș (St. Nifon, St. Filofteia, Serghie, Vach and Tatiana), Lume deșartă și degrabă trecătoare [Vain and Fast-Fleeting World], tone 5 a.o., apud Gheorghe C. Ionescu, op. cit., p. 391. 
Varlaam and Schemamonk Nektarios, but especially of the chants composed by I. Zmeu, his mentor"1(our translation).

Between 1947 and 1989, a small number of psaltic chants were published in the journals "Biserica Ortodoxă Română" [The Romanian Orthodox Church], printed by the Romanian Patriarchate and "Glasul Bisericii" [The Voice of the Church], printed by the Metropolitan See of Ungro-Wallachia. The pages of these periodicals were welcoming hosts for the timid appearances of psaltic compositions that managed to dodge the censorship of the time. In 1970, Ioan Gh. Popescu (1925-1992) published Luminânda la Adormirea Maicii Domnului [Exapostilarion of the Dormition of the Mother of God], tone 3; Răspunsurile mari [The Great Responses], tone 3, in both notations, and Axion duminical [Sunday Axion], tone 3, in the journal "Biserica Ortodoxă Română" [The Romanian Orthodox Church $]^{2}$. Conductor of the Choir of the Metropolitan Cathedral of Sibiu (1954-1992) and professor at the Theological Institute of Sibiu, Ioan Gh. Popescu also followed the tendencies of the time and produced harmonizations and some choral compositions for the services of the Orthodox Church ${ }^{3}$.

It is also in the journal "Glasul Bisericii" [The Voice of the Church] that in 1988, Archd. Ph.D. Sebastian Barbu-Bucur published a Polihronion [Polychronion], tone 2, dedicated to His Beatitude Patriarch Teoctist ${ }^{4}$. A Doxologie [Doxology], tone 8 , was published in the same year in the journal "Mitropolia Olteniei" [The Metropolitan See of Oltenia] ${ }^{5}$.

In the same journal of the Metropolitan See of Oltenia, Alexie Buzera (1934-2011) published Slujba Sf. Grigore Cuvântătorul de Dumnezeu. Patronul Seminarului Teologic din Craiova [The Service of St. Gregory the Theologian. Patron of the Theological Seminary in Craiova] $]^{6}$. This happened in 1982, one year after he became the teacher of the Theological Seminary in the capital city of Oltenia. Catavasii la Duminica Fiului Risipitor [Katavasia of the Sunday of the Prodigal Son] ${ }^{7}$ saw the light of day only a few years later, although his compositional concerns

\footnotetext{
${ }^{1}$ Nicu Moldoveanu, op. cit., p. 132.

2 "Biserica Ortodoxă Română" [The Romanian Orthodox Church], Bucharest, Year LXXXVIII (1970), No. 7-8, July-Aug. pp. 837-856.

${ }^{3}$ For details see: Pr. Prof. Ph.D. Mircea Păcurariu, Dicționarul Teologilor Români [Dictionary of Romanian Theologians], Editura Enciclopedică, Bucharest, 1966, pp. 347-348, Vasile Stanciu, Muzica bisericească din Transilvania [Church Music in Transylvania], Presa Universitară Clujeană, Cluj-Napoca, 1966, pp. 223-225 and Nicu Moldoveanu, op. cit., p. 201.

${ }^{4}$ In "Glasul Bisericii" [The Voice of the Church], Bucharest, Year XLVII (1988), No. 4, July-Aug., pp. 166168.

5 "Mitropolia Olteniei" [The Metropolitan See of Oltenia], Craiova, Year XL, 1988, No. 3, May-June, pp. 137-144.

6 "Mitropolia Olteniei" [The Metropolitan See of Oltenia], Craiova, Year XXXIV (1982), Nos. 1-3 (Jan.-March), Anexă [Appendix], pp. 1-12.

7 Published in "Mitropolia Olteniei" [The Metropolitan See of Oltenia], Craiova, Year XXXIX (1987), No. 2 (March-April), pp. 139-142.
} 
were not absent, as proven by the numerous harmonizations of carols that he produced and published in the same metropolitan journal beginning with 1973.

As we can see, however, the printing of psaltic compositions (rendered only in neumatic notation) was possible only after 1980, during a period when the persecution against the monks and priests had diminished, although there had been a certain ideological relaxation already after 1965, when the censorship allowed the publication of some studies that dealt with "Byzantine music"1. However, it was the psaltic music written in double notation that dominated the period between 1951 and 1989.

\section{3. "After" 1989 - the decade that saw the revival of psaltic music}

A first sign of the changes brought by the Romanian Revolution of December 1989 was the release, on December 29, 1989 (just a few days after the condemnation and execution of dictator Ceaușescu), of the first issue of a new periodical published by the Romanian Patriarchate: "Vestitorul Ortodoxiei Românești" [The Herald of Romanian Orthodoxy]2. We mention this event especially because it is in this periodical that Archd. Ph.D. Sebastian Barbu-Bucur published, after 1990, his first psaltic composition: Rugăciune [Prayer], on verses by Vasile Militaru ${ }^{3}$. His name and the year 1990 are also linked to another event that illustrates the changes brought about by the new regime: one of the 1990 prizes of the Union of Composers and Musicologists was awarded to the volume Cultura muzicală de tradiție bizantină pe teritoriul României în secolul XVIII şi începutul secolului XIX şi aportul original al culturii autohtone [The Musical Culture of Byzantine Tradition on the Romanian Territory in the $18^{\text {th }}$ and Early $19^{\text {th }}$ Centuries and the Original Contribution of the Local Culture] $]^{4}$

With the establishment of democracy naturally came the attempt to recover the values lost during communism. The acute need for qualified staff for the many parishes that were reactivated or newly established in the many neighbourhoods of the cities led to the re-establishment of numerous pre-university and university educational institutions. In addition, following the

\footnotetext{
${ }^{1}$ Nicolae Gheorghiță, Cercetările de muzicologie bizantină în România totalitară [Byzantine Musicology Research in Totalitarian Romania], in the journal "Muzica", No. 7, 2015, p. 47.

2 "Until mid-1992, the periodical kept its original name: Vestitorul Ortodoxiei Românești [The Herald of Romanian Orthodoxy]. Then, for a year, it was simply Vestitorul [The Herald]. As of its 94th issue (15 May 1993), its name was established and has been preserved to this day as: Vestitorul Ortodoxiei [The Herald of Orthodoxy]." https://vestitorulortodoxiei.ro/istoric/

3 In "Vestitorul Ortodoxiei Românești" [The Herald of Romanian Orthodoxy], Bucharest, Year II, Nos. 13-14, 1VII 1990.

${ }^{4}$ Sebastian Barbu-Bucur, Cultura muzicală de tradiție bizantină... [The Musical Culture of Byzantine Tradition...], ed. cit., 1989.
} 
model of the old Academy of Religious Music, in 1990, Religious Music departments were established in the three long-standing music conservatories in Bucharest, Cluj-Napoca and Iași.

Shortly after that, along with the local initiatives meant to provide the musical material needed for the training of pupils and students, an editorial event brought to the fore a valuable psaltic repertoire with the publication of the volume Cântări la Sfânta Liturghie și alte cântări bisericești [Chants of the Divine Liturgy and Other Sacred Chants] ${ }^{1}$, in 1992.The necessity of the book is emphasized in Cuvântul înainte [Foreword] signed by His Beatitude Patriarch Teoctist (1915-2007): "We live moments of great joy, now when, - at last -, after a thorough and careful preparation of nearly four years, one of the most expected and comprehensive collections of traditional and contemporary church chants [...] used in the Romanian Orthodox Church finally sees the light of day"2 (our translation). On the other hand, we must note that the volume had been designed during the last years of dictatorship ${ }^{3}$, which explains the use of the double notation, which was stubbornly present in the last decades of the last century in all the church music publications. It is also important to emphasize the fact that, together with the consecrated chanters of the $19^{\text {th }}$ century and the composers of the first half of the $20^{\text {th }}$ century, this anthology also included original works signed by Archd. Ph.D. Sebastian Barbu-Bucur ${ }^{4}$, Pr. Prof. Ph.D. Nicu Moldoveanu ${ }^{5}$, Florin Bucescu, Marin Velea, Victor Frangulea, Ion Gavrilă.

The change of the political regime enabled the return to the tradition of the psaltic chant by reissuing collections of well-known church songs of the first half of the $20^{\text {th }}$ century, used in the performance of the religious services: Liturghierul de strană [The Liturgy Book for the Choir] by Ion Popescu-Pasărea ${ }^{6}$, the three volumes

${ }^{1}$ Cântări la Sfânta Liturghie și alte cântări bisericești [Chants of the Divine Liturgy and Other Church Chants], ed. cit.

${ }_{2}^{2}$ Cântările Sfintei Liturghii [The Chants of the Divine Liturgy], Editura Institutului Biblic și de Misiune al B.O.R., Bucharest, 1992, p. 3.

${ }^{3}$ On the same page 3 of the text it is stated that "this is in fact an action that continues the work initiated by the great Patriarch Justinian [...] at the beginning of the $6^{\text {th }}$ decade, an action that has proven to be of ever-greater importance to the Romanian spirituality, especially as the atheist hostility in which church life was carried out deprived the Orthodox church of both books and chanters" (our translation).

4 The following compositions by father Sebastian Barbu-Bucur are included: Laudă suflete al meu [Praise the Lord, O My Soul] (Ps. 145) tone 8 (p. 91); Iubi-Te-voi, Doamne [I Will Love Thee O Lord], tone 5 (p. 122), Iubi-Te-voi, Doamne [I Will Love Thee O Lord], tone 7 (p. 123), Am văzut lumina [I Saw the Light], tone 5 (p. 208), Să se umple gurile noastre [Let Our Mouths Be Filled], tone 5 (pp. 209-210).

${ }^{5}$ The following compositions by father Nicu Moldoveanu are included: De tine se bucură [All of Creation Rejoices in You], tone 5 (pp. 55- 56), Iubi-Te voi, Doamne [I Will Love Thee O Lord], tone 8 (p. 124) and a chant by Ioan Zmeu, revised by father N. Moldoveanu - Bine voi cuvânta pre Domnul [I Shall Praise the Lord], tone 2 (p. 210).

${ }^{6}$ Ion Popescu-Pasărea, Liturghier de strană [Liturgy Book for the Choir], Editura Arhiepiscopiei Tomisului, 2001. 
of the Idiomelar [Idiomelarion] by Dimitrie Suceveanu1, Anastasimatar [Anastasimatarion] by Victor Ojog2. The appearance of these chants brought back the question of the standardized repertoire and of writing the chants in double notation. Gradually, both the repertoire and the double notation disappeared, it being considered that only the neumatic notation can be used for a chant sung in the traditional psaltic style. In this regard, the supervisors of the 1999 edition of Victor Ojog's Anastasimatar [Anastasimatarion] wrote the following in the introductory word to the book: “... as long as the chants are in double notation (psaltic and linear), the pupils and students will not learn psaltic music (our emphasis). They come to the theological schools with a minimal knowledge of linear music ... which they use empirically in order to follow only the meaning of the melodic-rhythmic diagram, which diverts them from reading the psaltic neumes, which are the only ones that can render the authentic song"3 (our translation).

In the last decade of the $20^{\text {th }}$ century, psaltic composition became increasingly prominent due to several personalities trained during the interwar period in the famous seminaries and in important theological higher-education establishments: Archd. Ph.D. Sebastian Barbu-Bucur Ph.D., Pr. Nicu Moldoveanu, Ph.D., Pr. Alexie Buzera, Ph.D., Pr Florin Bucescu, Ph.D.. We will briefly mention only some of their works, published until 2000.

The psaltic works of Archd. Ph.D. Sebastian Barbu-Bucur (1930-2015) is very comprehensive, including, alongside the chants published sporadically in specialized journals ${ }^{4}$ and the two volumes of Cântări psaltice pentru cursul de muzică religioasă [Psaltic Songs for the Religious Music Class] (1991, 1994), the 33 services for the Romanian saints canonized by the Romanian Orthodox Church in 1991 and 1992. Two of them were published in the last century: Slujba Sfântului Cuvios Iacob de la Neamț [Service to Saint Pious Jacob of Neamț] (1996) and Slujba Sfintei Cuvioase Teodora de la Sihla [Service to Saint Pious Theodora of Sihla] (1997). However, most of his compositions were published after 2000, a period not dealt with in this paper. We have analysed some of his works and noticed that "with his works, Archhd. Sebastian Barbu-Bucur, Ph.D. marks a new stage in the long process of adaptation of the church chant of Byzantine tradition to the Romanian language [...] because, by writing them directly to Romanian text, he creatively uses the accumulations of the previous two centuries, managing to condense the most prominent features of the traditional psaltic style into an original form, in which

\footnotetext{
1 Dimitrie Suceveanu, Idiomelar [Idiomelarion], vol. I, Editura Mănăstirii Sinaia, 1992; vol II, Editura Mitropoliei Moldovei, Iași, 1996.

2 Victor Ojog, Anastasimatar [Anastasimatarion], ed. cit.

${ }^{3}$ Idem, p. VI.

4 The complete list of the works published until 2010 can be found in Sebastian Barbu-Bucur octogenar [Sebastian Barbu-Bucur, Octogenarian], SemnE, Bucharest, 2010, pp. 48-54.
} 
the chanter's skill combines with the refinement of the well-informed researcher" (our translation) ${ }^{1}$.

Father Professor Ph.D. Nicu Moldoveanu (b. 1940) has published numerous harmonic reworkings of psaltic chants, and also composed and published various collections of megalynaria, troparia, kontakia, sessional hymns, stichera, praises, kontakia of the Akathist hymn of several feasts of the year. Some were published in Noul Idiomelar [The New Idiomelarion] (1999), an edition prepared by Nicu Moldoveanu after the one translated by Dimitrie Suceveanu in the 19th century (1856) and the one later compiled by Ion Popescu-Pasărea (1933), and completed with his own works, troparia and kontakia, as well as chants from the services to Saint Pious Dimitrios the New, the Holy Martyr Catherine, Saint Eleftherios, the Hieromartyr and Bishop of Illyria.

The events of 1989 allowed Prof. Ph.D. Alexie Buzera from the Faculty of Orthodox Theology in Craiova to include his psaltic creation in a collection entitled Toată suflarea să laude pe Domnul. Cântări bisericești, pricesne și imnuri religioase, colinde și cântece de stea culese și revizuite de Alexie Buzera [Let Everything That Has Breath Praise the Lord. Church Chants, 'Priceasna' and Other Religious Hymns, Christmas Carols and Songs Collected and Reviewed by Alexie Buzera] (1991), which also illustrates his interests in the field of folklore.

Concerned with the research of the musical manuscripts from Moldova, but also with the provision of a suitable musical material for the formation of the future church servants, Pr. Prof. Ph.D. Florin Bucescu (b. 1936), professor at the Theological Seminary and at the Religious Music Department of the Iași Conservatory, composed a Liturghie psaltică în glasul III - ga [Psaltic Liturgy in Tone 3 - Ga]. It is known that in the previous period, the most frequently promoted liturgical repertoire was in tones 5 and 8 . The reason for choosing tone 3 is justified by the father-teacher in the introduction to the volume: "for the revival of the psaltic repertoire of the students of the «St. Basil the Great» Orthodox Theological Seminary in Iași"2 (our translation). In the volume published in 2006, this version of the liturgy also has choral variants for two and three voices, written by composer Vasile Spătărelu from Iași.

Described as "... a lover of psaltic music which he serves and cultivates in the authentic traditional spirit" (our translation), father-teacher Victor Frangulea (b. 1939) composed, in addition to choral music works in psaltic style, Slujba Sf. Ghelasie [Religious Service to St. Gelasius] (Romanian saint from

\footnotetext{
${ }^{1}$ Elena Chircev, Ipostaze ale stilului neo-bizantin. Slujba Sf. Ioan cel Nou de la Neamț de arhid. dr. Sebastian Barbu-Bucur [Illustrations of the Neo-Byzantine Style. Religious Service to St. John the New of Suceava by Archd. Ph.D. Sebastian Barbu-Bucur], in Elena Chircev, Amprente românești în muzica de tradiție bizantină [Romanian Elements in the Music of Byzantine Tradition], Editura Risoprint, Cluj-Napoca, 2013, p. 236.

${ }^{2}$ Florin Bucescu, Liturghia psaltică în glasul III ga. [Psaltic Liturgy in Tone 3 - Ga], Trinitas, Iași, 2006, p. 8.
} 
Transylvania), canonized by the Romanian Patriarchate in 1992, rendered in neumatic notation. ${ }^{1}$

The small number of composers and of works published in the last decade of the second Christian millennium is explainable if we consider the reprisals against the priests and monks during the totalitarian regime, as well as the harsh conditions in which theological education survived during this time. However, their existence was a signal for the development of church music that was to come in the first decades of the third millennium.

\section{Conclusions}

In a study dedicated to the research on Byzantine musicology conducted in totalitarian Romania, musicologist Nicolae Gheorghiță finally reached the conclusion that "... of all the branches of musicology, the studies on Byzantine music in communist Romania constituted, paradoxically, the field that enjoyed the greatest promotion, transparency and international interest" 2 (our translation). This cannot be said of psaltic music composition, which for decades lacked a favourable framework for development, impossible to imagine in the atheist communist state. As a synthesis of the above, we can draw some conclusions regarding the influence exerted by the changes of political regime in Romania, twice in the space of 42 years, on musical creation in the spirit of the Byzantine tradition.

It is obvious that the communist regime prevented the free manifestation of creativity in the field of psaltic music. Because of the adverse conditions that occurred after 1947, church music had a hard time surviving the totalitarian regime, so that psaltic music creation became a rarity.

At the distance of half a century, understanding the context and appreciating the efforts made to maintain church life in its entirety, we notice, however, that despite being meant to save church music, the measures taken in the post-war period affected the traditional style of the psaltic chant by imposing the "standardized" repertoire. Rendering the psaltic monody in double notation deteriorated the authentic psaltic style transmitted by the interwar generation, formed by the chanters who had received their musical education from teachers trained at the end of the $19^{\text {th }}$ century and who had been taught by some of the most famous chanters of the time ${ }^{3}$. Accompanying the neumes with notes written on the

\footnotetext{
${ }^{1}$ Gheorghe C. Ionescu, Muzica bizantină... [Byzantine Music...], ed. cit., p. 501.

2 Nicolae Gheorghiță, Cercetările de muzicologie bizantină în România totalitară [Byzantine Musicology Research in Totalitarian Romania], ed. cit.

${ }^{3}$ We take as example Archd. Ph.D. Sebastian Barbu-Bucur, a student of Atanasie Dincă and Victor Ojog, at the Seminary of the Neamț Monastery. Both teachers had been students of Ion Popescu-Pasărea (A. Dincă at the "Metropolitan Nifon" Seminary in Bucharest, and V. Ojog at the Academy of Religious Music). In his turn, he had studied with Ștefanache Popescu at the "Metropolitan Nifon" Seminary,
} 
staff led to a departure from the traditional style, because staff notation cannot reproduce all the subtleties of Byzantine notation.

On the other hand, the abolishment of numerous singers' schools, seminaries and monasteries, along with the younger monks' obligation to work in factories and plants affected the oral component of the Byzantine tradition, which, along with the written one, had ensured its continuity over the centuries, as well as the development of the chanting skills and of a certain style of interpretation.

We also note that, in addition to the official censorship, which was discouraging for the creative manifestations that exceeded the framework set by the political factor, self-censorship also occurred to a great extent, fuelled by the general atmosphere in which delation was synonymous with the protection of the national interests. This explains the small number of psaltic music compositions published or preserved in manuscript form in the decades of the totalitarian regime.

The speed with which the thread of tradition was reinstated beginning with 1990 was made possible by the chanters trained in the theological and interwar seminaries, graduates of theology faculties, who completed their musical studies in conservatories in the sixth decade and secretly remained faithful defenders of Orthodoxy. They are those who before 1990 composed and sometimes managed to publish one or two psaltic chants in theological journals and who contributed to the re-editing of the valuable collections of church songs of the interwar period, as well as to the revival of musical education in the theological schools, in the good spirit of the psaltic tradition learned from their teachers.

Beginning with the year 2000, psaltic creation became increasingly prominent and important through the contribution of Archd. Ph.D. Sebastian Barbu-Bucur and of Prof. Ph.D. Nicu Moldoveanu. In the years to come, the generations of theologians trained in the Religious Music Department of the National University of Music in Bucharest and in that of the "George Enescu" University of Arts in Iași will no doubt continue to enrich the religious services performed in the Romanian churches with their works.

\section{BIBLIOGRAPHY}

\section{BOOKS}

BARBU-BUCUR, Sebastian, Cultura muzicală de tradiție bizantină pe teritoriul României în secolul XVIII şi începutul secolului XIX şi aportul original al culturii autohtone, Editura Muzicală, Bucharest, 1989

while in the mid-19th century, while Ștefanache Popescu had studied with Hristodor Geogis (Gheorghiade), an appreciated Greek musician of the time and, apparently, also with Anton Pann (see Gh. C. Ionescu, op. cit., p. 165). 
BARBU-BUCUR, Sebastian, Filothei sin Agăi Jipei - Psaltichie rumănească, vol. I, Catavasier, Editura Muzicală, Bucharest, 1981

BUCESCU, Florin, Manuscrisele psaltice al lui Teodor Stupcanu, in Florin Bucescu, Bizantinologie muzicală. Studii și articole. Liturghia psaltică în glasul al III-lea, Artes, Iași, 2018

CATRINA, Constantin, Fișă de lexicon, in Sebastian Barbu-Bucur octogenar, SemnE, Bucharest, 2010

CHIRCEV, Elena, Tradiție și modernitate în creația psaltică actuală. Cântări ale Vecerniei de arhid. dr. Sebastian Barbu-Bucur, in Elena Chircev, Amprente românești în muzica de tradiție bizantină, Risoprint, Cluj-Napoca, 2013

CHIRCEV, Elena, Ipostaze ale stilului neo-bizantin. Slujba Sf. Ioan cel Nou de la Neamț de arhid. dr. Sebastian Barbu-Bucur, in Elena Chircev, Amprente românești în muzica de tradiție bizantină (pp. 211-224), Risoprint, Cluj-Napoca, 2013

CHIRCEV, Elena, Mărturii și dialoguri despre muzica bizantină, Risoprint, Cluj-Napoca, 2013

CIOROIANU, Adrian, Pe umerii lui Marx. O introducere în istoria comunismului românesc, Curtea veche, Bucharest, 2005

CIOBANU, Gheorghe, Studii de etnomuzicologie și bizantinologie, vol. II, Editura Muzicală, Bucharest, 1979

GIULEANU, Victor, Melodica bizantină, Editura Muzicală, Bucharest, 1981

GIURESCU, Dinu C., România în Al Doilea Război Mondial, Editura ALL EDUCATIONAL, Bucharest, 1999

IONESCU, Gheorghe C., Filotei Monahul de la Cozia (sec. XIV-XV). Pripelele după Polieleu, in Studii de muzicologie și bizantinologie, [publisher not identified], Bucharest, 1997, pp. 9-41

IONESCU, Gheorghe C., Muzica bizantină în România. Dicționar cronologic, Sagittarius, Bucharest, 2003

MATRESCU, Florin, Holocaustul roșu sau crimele în cifre ale comunismului internațional, Editura IRECSON, Bucharest, 2008

MOISESCU, Titus, Prolegomene bizantine. Muzică bizantină în manuscrise și carte veche românească, Editura Muzicală, Bucharest, 1985

MOISESCU, Titus, Putna - un puternic centru de cultură muzicală medievală românească, in T. Moisescu, Muzica bizantină în spațiul cultural românesc, Editura Muzicală, Bucharest, 1996

MOISESCU, Titus, Preotul Ioan D. Petrescu-Visarion. Ctitor al Școlii românești de muzică bizantină, in Monodia bizantină în gândirea unor muzicieni români, Editura Muzicală, Bucharest, 1999

MOLDOVEANU, Nicu, Istoria muzicii bisericești la români, Editura Basilica a Patriarhiei Române, Bucharest, 2010

PANCZA, David, The Filotean Pripela: Analysis of Text and Melody, in Unity and Variety in Orthodox Music: Theory and Practice. Proceedings of the Fourth International Conference on Orthodox Church Music. University of Joensuu, Finland, 6-12 June 2011. Moody I. and Takala-Roszczenko M. (ed.), The International Society of Orthodox Church Music, Joensuu, 2013, pp. 472-476

PENNINGTON, Anne E., Muzica în Moldova Medievală (secolele XV-XVI), bilingual edition supervised by Titus Moisescu, Editura Muzicală, Bucharest, 1985 
PĂCURARIU, Mircea, Istoria Bisericii Ortodoxe Române, vol. I, 2nd edition, Bucharest, Editura Institutului Biblic și de Misiune al Bisericii Ortodoxe Române, 1992

PĂIUȘAN, Cristina, ION, Narcis Dorin, RETEGAN, Mihai, Regimul comunist în România O cronologie politică (1945-1989), Tritonic, Bucharest, 2002

POPESCU-PASĂREA, Ion, Muzica bisericească, in Petre Nițulescu (ed.), Muzica românească de azi. Cartea sindicatului artiștilor instrumentiști din România, Institutul de Arte Grafica MARVA. S.A.R., Bucharest, 1939

VASILE, Vasile, Istoria muzicii bizantine și evoluția ei în spiritualitatea românească, vol. II, Interprint, Bucharest, 1997

VELICU, Dudu, Biserica Ortodoxă în anii regimului comunist. Insemnări zilnice II, 1948-1959, edition supervised by Alina Tudor-Pavelescu and Șerban Marin, Arhivele Naționale ale României, Bucharest, 2005

\section{JOURNALS}

* * *, Lucrările Sfântului Sinod al Bisericii Ortodoxe Române. Importante hotărâri luate de Sfântul Sinod în sesiunea din iunie 1952, in "Biserica Ortodoxă Română", No. 9-10, 1952

CHIRCEV, Elena, Tradition and Modernity in Current Psaltic Music. Vespers Hymns by Archdeacon Dr. Sebastian Barbu-Bucur, in "Musicology Papers", vol. XXVI No. 2, MediaMusica, Cluj-Napoca, 2012, pp. 54-64

CHIRCEV, Elena, "Mereu neînfrânt!" Interviu cu arhid. dr. Sebastian Barbu-Bucur, in "Tabor. Revistă lunară de cultură şi spiritualitate românească", published by the Metropolitan See of Cluj, Alba, Crişana and Maramureş, Cluj-Napoca, Year IV, April, 2010, No. 1, pp. 77-84

CHIRCEV, Elena, Romanian Music of Byzantine Tradition Between 1918 and 2018, in "Artes. Journal of Musicology", vol. 19-20, Iași, 2019

GHEORGHIȚĂ, Nicolae, Cercetările de muzicologie bizantină în România totalitară, in "Muzica", No. 7, 2015

\section{CHURCH CHANT COLLECTIONS}

* * * Cântările Sfintei Liturghii și alte cântări bisericești, Editura Institutului Biblic și de Misiune al B.O.R., Bucharest, 1992

BARBU-BUCUR, Sebastian, Doxologie, in "Mitropolia Olteniei", Craiova, XL (1988), No. 3 (May-June), pp. 137-144

BARBU-BUCUR, Sebastian, Polihronion in "Glasul Bisericii", Bucharest, Year XLVII (1988), No. 4 (July-Aug.) pp. 166-168

BARBU-BUCUR, Sebastian, Rugăciune, in "Vestitorul Ortodoxiei Românești", Bucharest, Year II, Nos. 13-14, 1 VII 1980

BARBU-BUCUR, Sebastian, Cântări psaltice pentru cursul de muzică religioasă, vol. I, 1991, vol. II, 1994, The Publishing House of the Bucharest Music Academy

BARBU-BUCUR, Sebastian, Cântări la Vecernie, Utrenie și Sfânta Liturghie, SemnE, Bucharest, 2009

BUCESCU, Florin, Liturghia psaltică în glasul III ga, Trinitas, Iași, 2006

BUZERA, Alexie, Slujba Sf. Grigore Cuvântătorul de Dumnezeu. Patronul Seminarului Teologic din Craiova, in "Mitropolia Olteniei", Craiova, Year XXXIV (1982), Nos. 1-3 (Jan.-March), Appendix, pp. 1-12 
BUZERA, Alexie, Catavasii la Duminica Fiului Risipitor, in: "Mitropolia Olteniei”, Craiova, Year XXXIX (1987), No. 2 (March-April), pp. 139-142

BUZERA, Alexie, Toată suflarea să laude pe Domnul. Cântări bisericești, pricesne și imnuri religioase, colinde și cântece de stea culese și revizuite de Alexie Buzera, Editura Europa, Craiova, 1991

CATRINA, Constantin, Fișă de lexicon, in: Sebastian Barbu-Bucur octogenar, SemnE, Bucharest, 2010

LUNGU, Nicolae, UNCU, Anton, Cântări liturgice omofone și cântări la Cateheze pe ambele semiografii suprapuse, Editura Institutului Biblic, Bucharest, 1951

LUNGU, Nicolae, COSTEA, Grigore, CROITORU, Ion, Gramatica muzicii psaltice. Studiu comparat cu notația liniară, Editura Institutului Biblic, Bucharest, 1951

LUNGU, Nicolae, COSTEA, Grigore, CROITORU, Ion, Anastasimatarul uniformizat. Vecernierul sau cântările vecerniei de sâmbătă seara ale celor opt glasuri bisericești, Editura Institutului Biblic, Bucharest, 1953

LUNGU, Nicolae, COSTEA, Grigore, CROITORU, Ion, Anastasimatarul uniformizat II. Cântările utreniei de duminică dimineața ale celor opt glasuri bisericești urmate de Svetilnele Evangheliilor și ale Doxologiei Mari, Editura Institutului Biblic, Bucharest, 1954

OJOG, Victor, Anastasimatar, 2nd Edition, Trinitas, Iași, 1999

STUPCANU, Theodor V., Anastasimatar sau cântările Invierii pe cele opt glasuri (melodii) bisericești, Tipografia cărților bisericești, Bucharest, 1926

\section{WEBOGRAPHY}

* * *, Decretul nr. 177/1948, see: Legislative portal, http://legislatie.just.ro/Public/DetaliiDocumentAfis/47

* * *, Vestitorul Ortodoxiei, https://vestitorulortodoxiei.ro/istoric/

ENACHE, George, Decretul 410/1959. Un scurt bilanț la 50 de ani de la adoptare, "Lumina" journal, 28 October, 2009, http://ziarullumina.ro/decretul-410-1959-un-scurt-bilant-la50-de-ani-de-la-adoptare-37899.html 